\title{
KRITIK OTORITARIANISME TEKS DENGAN PISAU HERMENEUTIK; KAJIAN TERHADAP PEMIKIRAN KHALED M ABOU KHALED
}

\author{
Alfi Qonita Badi'ati \\ Dosen Manajemen Dakwah IAIN Salatiga \\ qonitahelwa@gmail.com
}

\begin{abstract}
Khaled is one of scholars who is really anxious to the Islamic law. He against the fatwas produced by some institutions or certain scholars, especially, a fatwa regarding fiqh as the final solutions of ummah. Eventually, these instructions are considered to be authoritarian or discrimination for the weak class. The methodological errors in understanding the Islamic resources are the causes of the emergence of authoritarianism phenomenon. Khaled offers the hermeneutic methode to solve these problems. Methodology of Khaled's hermeneutic consists of three elements; determination of meaning, text competence, and the concept of representation in Islam. Using the hermeneutic approach, Islamic law produced, is expected to be authoritative, innovative, and dynamic.
\end{abstract}

Keywords: Authoritarianism, Hermeneutic, Teks.

\begin{abstract}
Abstrak
Khaled merupakan salah satu cendikiawan muslim yang tertarik dibidang hukum Islam. Ia menentang fatwa yang dibuat beberapa lembaga atau beberapa cendikiawan khususnya fatwa mengenai fiqih sebagai solusi akhir umat. Pada akhirnya fatwa ini dianggap otoriter dan diskriminatif terhadap kalangan lemah. Kesalahan metode dalam memahami sumber-sumber kajian islam merupakan penyebab munculnya fenomena keotoriteran tersebut. Khaled menawarkan sebuah metode hermeneutik untuk mengatasi masalah tersebut. Metode hermeneutik Khaled terdiri dari tiga elemen: penentuan makna, kompetensi teks, dan konsep penafsiran dalam Islam. Dengan menggunakan pendekatan hermeneutik, hukum Islam yang terbentuk diharapkan menjadi berwibawa, inovatif, dan dinamis.
\end{abstract}

Kata Kunci: Otoritarianisme, Hermeneutik,Teks 
INJECT: Interdisciplinary Journal of Communication, Vol.1, No.1, Juni 2016: h. 43-62

\section{Pendahuluan}

Al-Quran sebagai kitab suci umat Islam, karena hal tersebut dalam memandang kitab suci harus dilihat bahwa ada dua fakta penting. Pertama, Tuhan dan FirmanNya dan kedua, penerimaan individu terhadap kalam tersebut. Pendek kata kitab suci sejak awal mengandaikan adanya dua belah pihak yang saling berdialektika, kitab suci dan manusia sebagai pembaca.

Penafsiran terhadap al-Quran merupakan tahapan awal yang menentukan ekspresi keberagamaan seseorang, karena pada dasarnya agama mengandaikan hadirnya struktur masyarakat yang mengakui sebuah otoritas Muhammad, diakui sebagai individu sentral yang mewakili kehendak Tuhan di dunia. Sebagai penerima kalam ilahi, Muhammad secara efektif memegang otoritas masyarakat Muslim periode awal. Sepeninggal beliau, munculah persoalan mengenai legitimasi otoritas selanjutnya. Oleh sebab itu mengabaikan alasan politis yang melatarbelakanginya, barbagai pembenaran teologis dikemukakan untuk mendukung peluang masing-masing pihak yang berjuang.

Pada abad kedua hijriah muncul pemegang otoritas sebagai Hukum Tuhan(Syariah) yang disajikan oleh sekelompok profesional yang akhirnya dikenal dengan fuqaha. Pada masa awal Islam, permisalan yang diberikan Nabi dan para sahabat dan ketentuan al-Quran membentuk dasar-dasar yang akhirnya melahirkan budaya hukum Islam yang spesifik. Namun setelah lahirnya kitab fiqh, budaya hukum yang bersifat teknis dengan bahasa, simbol, dan struktur yang spesifik menjadi sebuah institusi yang mapan. (Khaled, 2003:27)

Interpretasi terhadap hukum merupakan pemaknaan dari apa yang terkandung di dalamnya. Setiap hukum memiliki dua sisi penting yang tidak bisa dinafikan salah satunya; baik yang tersurat atau yang tersirat. Subtilitas intelligendi atau ketetapan pemahaman dan subtilitas exsplicandi atau ketetapan penjabaran yang keduanya merupakan hal yang 
urgen. Dalam hal ini pastilah hermeneutik diperlukan sebagai pisau asah interpretasi teks, dan ayat hukum pada khususnya. (Sumaryono, 1993:28)

Islamic Jurisprudence atau fiqh dianggap oleh sebagai teks paling otoritatif dalam menyelesaikan isu-isu kontemporer seperti HAM, gender, pluralisme, keadilan sosial, dan sebagainya, muncul ke permukaan. (Hasan, 2003:20). Kecenderungan ini terjadi tidak hanya di negara-negara yang mayoritas penduduknya beragama Islam, tetapi juga di dalam komunitas Muslim di negara-negara non-Muslim seperti Amerika Serikat. Fenomena ini merebak kepermukaan karena sebuah institusi fatwa Islam CRLO (Council for Scientific Research and Religious Legal Opinion) sebagai lembaga fatwa resmi Arab Saudi yang diikuti oleh muslim Dunia. Hal ini yang mendorong Khaled Medhat Abou Khaled untuk membahasnya lebih lanjut dan mengembangkan metode hermeneutiknya. Hal ini menjadi penting karena dengan adanya fatwa tersebut citra Islam ternodai menjadi Islam yang eksklusif, sectarian, primordial, dan anti perubahan.

\section{Sejarah Hermeneutika}

Dalam sejarah tentang teori bahasa sudah lama menjadi obyek kajian para ahli, sejak dari kalangan psikolog, antropolog, filsuf maupun teolog, sehingga lahirlah sub-sub ilmu dan bahasa, di antaranya adalah hermeneutika. Sifat ilmu pengetahuan itu sendiri adalah selalu berkembang dan berkaitan antara satu disiplin ilmu dengan disiplin ilmu yang lain. Dalam hermeneutika sering dikelompokkan dalam wilayah bahasa, meskipun ia bisa juga mengklaim sebagai disiplin ilmu tersendiri. Khususnya hermeneutika yang semula sangat dekat kerjanya dengan Biblical Studies, dengan munculnya buku Truth and Method (1960) oleh Hans-Geor Gadamer, maka hermeneutika mengembangkan mitra kerjanya pada semua cabang ilmu. Gadamer mendasarkan klaimnya pada argumen bahwa semua disiplin ilmu, termasuk ilmu alam, mesti terlibat dengan persoalan understanding yang muncul antara hubungan 
INJECT: Interdisciplinary Journal of Communication, Vol.1, No.1, Juni 2016: h. 43-62

subyek dan obyek (Hidayat, 1996:28).

Hermeneutika merupakan kata yang sering didengar dalam bidang teologi, filsafat, bahkan sastra. Kata hermeneutik baru muncul sebagai sebuah gerakan dominan dalam teologi Protestan Eropa, yang menyatakan bahwa hermeneutika merupakan 'titik fokus' dari isu-isu teologis sekarang. Martin Heidegger terus melakukan diskusi karakter hermeneutis dari pemikirannya. Termasuk filsafat itu sendiri, kata Heidegger, bersifat atau harus bersifat hermeneutics (Palmer, 2005:3).

Sesungguhnya istilah hermeneutika ini bukanlah sebuah kata baku, baik dalam filsafat maupun penelitian sastra; dan bahkan dalam bidang teologi penggunaan term ini sering muncul dalam makna yang sempit yang berbeda dengan penggunaan secara luas dalam "hermeneutika baru" teologis kontemporer (Palmer, 2005:4).

Hermeneutika selalu berpusat pada fungsi penafsiran teks. Meski terjadi perubahan dan modifikasi radikal terhadap teori-teori hermeneutika, tetap saja berintikan seni memahami teks. Pada kenyataannya, hermeneutika pra-Heidegger sebelum abad 20 tidak membentuk suatu tantangan pemikiran yang berarti bagi pemikiran agama, sekalipun telah terjadi evaluasi radikal dalam aliran-aliran filsafat hermeneutika. Sementara itu, hermeneutika filosofis dan turunannya dalam teori-teori kritik sastra dan semantik telah merintis jalan bagi tantangan serius yang membentur metode klasik dan pengetahuan agama.

Dalam perkembangannya metode hermeneutika lahir dalam ruang lingkup yang khas dalam tradisi Yahudi-Kristen. Perkembangan khusus dan luasnya opini tentang sifat dasar Perjanjian Baru, dinilai memberi sumbangan besar dalam mengentalkan problem hermeneutis dan usaha berkelanjutan dalam menanganinya.

Para filosof hermeneutika adalah mereka yang sejatinya tidak membatasi petunjuk pada ambang batas tertentu dari segala fenomena wujud. Mereka selalu melihat segala sesuatu yang ada di alam ini sebagai 
petunjuk atas yang lain. Jika kita mampu membedakan dua kondisi ini satu dan yang lainnya, maka kita dapat membedakan dua macam fenomena ilmu dan pemahaman. Masalah ilmu dikaji dalam lapangan epistemologi, sedangkan masalah pemahaman dikaji dalam lapangan hermeneutika. Sehingga dengan demikian, baik epistemologi dan hermeneutika adalah ilmu yang berdampingan.

Sebelum mendefinisikan hermeneutika, harus mengetahui terlebih dahulu asal-mula kata hermeneutika. Sudah umum diketahui bahwa dalam masyarakat Yunani tidak terdapat suatu agama tertentu, tapi mereka percaya pada Tuhan dalam bentuk mitologi. Sebenarnya dalam mitologi Yunani terdapat dewa-dewi yang dikepalai oleh Dewa Zeus dan Maia yang mempunyai anak bernama Hermes. Hermes dipercayai sebagai utusan para dewa untuk menjelaskan pesan-pesan para dewa di langit. Dari nama Hermes inilah konsep hermeneutic kemudian digunakan(Zarkasyi, 2006:1). Kata hermeneutika yang diambil dari peran Hermes adalah sebuah ilmu dan seni menginterpretasikan sebuah teks.

Hermes diyakini oleh Manichaeisme sebagai Nabi. Dalam mitologi Yunani, Hermes yang diyakini sebagai anak dewa Zeus dan Maia bertugas menyampaikan dan menginterpretasikan pesan-pesan dewa di gunung Olympus ke dalam bahasa yang dipahami manusia. Hermes mempunyai kaki bersayap dan dikenal dengan Mercurius dalam bahasa Latin. Menurut Abed al-Jabiri dalam bukunya Takw $\square \mathrm{n}$ al-'Aql al-'Ârabi, dalam mitologi Mesir kuno, Hermes atau Thoth adalah sekretaris Tuhan atau orisin Tuhan yang telah menulis disiplin kedokteran, sihir, astrologi dan geometri (http://irwanmasduqi83.blogspot.com/2008/09/kritikproyek-kritik-nalar-arab-abed-al.html). Hermes yang dikenal oleh orang Arab sebagai Idris as, disebut Enoch oleh orang Yahudi. Baik Idris as, Hermes, Thoth, dan Enoch adalah merupakan orang yang sama.

Sosok Hermes ini oleh Sayyed Hossein Nasr kerap diasosiasikan sebagai Nabi Idris as. Menurut legenda yang beredar bahwa pekerjaan 
Nabi Idris adalah sebagai tukang tenun. Jika profesi tukang tenun dikaitkan dengan mitos Yunani tentang peran dewa Hermes, ternyata terdapat korelasi positif. Kata kerja "memintal" dalam bahasa latin adalah tegree, sedang produknya disebut textus atau text, memang merupakan isu sentral dalam kajian hermeneutika. Bagi Nabi Idris as atau Dewa Hermes, persoalan yang pertama dihadapi adalah bagaimana menafsirkan pesan Tuhan yang memakai "bahasa langit" agar bisa dipahami oleh manusia yang menggunakan bahasa "bumi". Di sini barangkali terkandung makna metaforis tukang pintal, yakni memintal atau merangkai kata dan makna yang berasal dari Tuhan agar nantinya pas dan mudah dipahami (dipakai) oleh manusia(Hidayat, 1996:126).

Hermeneutika (Indonesia), hermeneutics (Inggris), dan hermeneutikos (Greek) secara bahasa punya makna menafsirkan. Seperti yang dikemukakan Zygmunt Bauman, hermeneutika berasal dari bahasa Yunani hermeneutikos berkaitan dengan upaya "menjelaskan dan memelusuri" pesan dan pengertian dasar dari sebuah ucapan atau tulisan yang tidak jelas, kabur, dan kontradiksi, sehingga menimbulkan keraguan dan kebingungan bagi pendengar atau pembaca (Hidayat, 1996:126).

Akar kata hermeneutika berasal dari istilah Yunani dari kata kerja hermēneuein (menafsirkan) atau kata benda hermèneia atau interpretasi (Palmer, 2005:14). Al-Farabi mengartikannya dengan lafal Arab al-ibāroh atau ungkapan. Kata Yunani hermeios mengacu kepada seorang pendeta bijak Delphic. Kata hermeios dan kata kerja hermèneuien dan kata benda hermèneia biasanya dihubung-hubungkan dengan Dewa Hermes, dari situlah kata itu berasal. Hermes diasosiasikan dengan fungsi transmisi apa yang ada di balik pemahaman manusia ke dalam bentuk apa yang dapat ditangkap oleh intelegensia manusia(Palmer, 2005:15). Kurang lebih sama dengan Hermes, seperti itu pulalah karakter dari metode hermeneutika.

Dengan menelusuri akar kata paling awal dalam Yunani, orisinalitas kata modern dari hermeneutika dan hermeneutis mengasumsikan pro- 
ses "membawa sesuatu untuk dipahami", terutama seperti proses ini melibatkan bahasa, karena bahasa merupakan mediasi paling sempurna dalam proses(Palmer, 2005:14).

Mediasi dan proses membawa pesan "agar dipahami” yang diasosiasikan dengan Hermes ini terkandung di dalam tiga bentuk makna dasar dari hermèneuien dan hermèneia dalam penggunaan aslinya. Tiga bentuk ini menggunakan bentuk kata kerja dari hermèneuein, yaitu: (1) mengungkapkan kata-kata, misalnya "to say"; (2) menjelaskan; (3) menerjemahkan. Ketiga makna itu bisa diwakilkan dalam bentuk kata kerja bahasa Inggris, "to interpret." Tetapi masing-masing ketiga makna itu membentuk sebuah makna independen dan signifikan bagi interpretasi(Palmer, 2005:16).

Sebagai turunan dari simbol dewa, hermeneutika berarti suatu ilmu yang mencoba menggambarkan bagaimana sebuah kata atau suatu kejadian pada waktu dan budaya yang lalu dapat dimengerti dan menjadi bermakna secara eksistensial dalam situasi sekarang. Dengan kata lain, hermeneutika merupakan teori pengoperasian pemahaman dalam hubungannya dengan interpretasi terhadap sebuah teks.

Persoalan utama hermeneutika terletak pada pencarian makna teks, apakah makna obyektif atau makna subyektif. Perbedaan penekanan pencarian makna pada ketiga unsur hermeneutika: penggagas, teks dan pembaca, menjadi titik beda masing-masing hermeneutika. Titik beda itu dapat dikelompokkan menjadi tiga kategori hermeneutika: hermeneutika teoritis, hermeneutika filosofis, dan hermeneutika kritis.

Pertama, hermeneutika teoritis. Bentuk hermeneutika seperti ini menitikberatkan kajiannya pada problem "pemahaman", yaknibagaimana memahami dengan benar. Sedang makna yang menjadi tujuan pencarian dalam hermeneutika ini adalah makna yang dikehendaki penggagas teks. Kedua, hermeneutika filosofis. Problem utama hermeneutika ini bukanlah bagaimana memahami teks dengan benar dan obyektif sebagaimana 
hermeneutika teoritis. Problem utamannya adalah bagaimana "tindakan memahami" itu sendiri. Ketiga, hermeneutika kritis. Hermeneutika ini bertujuan untuk mengungkap kepentingan di balik teks. hermeneutika kritis menempatkan sesuatu yang berada di luar teks sebagai problem hermeneutiknya.

\section{Biografi dan Karya Khaled M. Abou Khaled}

Khaled Medhat Abou Khaled merupakan nama lengkap dari Khaled. Dilahirkan di Kuwait pada tahun 1963. Salah satu negara di Timur Tengah dengan berbagai permasalahan yang pelik, baik masalah politik, ideologi, dan berimbas ke masalah lain seperti ekonomi. Sebagaimana tradisi bangsa Arab yang memegang teguh tradisi hafalan, Khaled kecil yang cerdas sudah hafal al-Quran sejak usia duabelas tahun. (Matswah, 2013:253)

Perjalanan pendidikannya diawali dari belajar pada para ahli fiqh. Setiap liburan musim panas, Khaled menghabiskan waktunya dengan mempelajari ilmu-ilmu syariah di masjid al-Azhar. Diantara guru yang ia kagumi adalah Syekh Muhammad al-Ghazali, salah satu ilmuan yang moderat. Dua Negara yang ia tinggali, baik Kuwait maupun Mesir adalah Negara yang tidak memberikan kebebasan berfikir secara penuh kepada masyarakatnya. Khaled dewasa yang merasa terkekang dengan keadaan tersebut akhirnya hijrah ke Amerika Serikat. Negara Adi Kuasa yang terkenal dengan sekulernya, mendorong Khaled untuk mengembangkan pemikirannya di sana.

Khaled melanjutkan jenjang pendidikan ke Yale University of America dalam bidang ilmu politik. Empat tahun kemudian Khaled menyelesaikan studi bachelornya dengan predikat magna cumlaude, sangat memuaskan. Ia juga mengambil studi Magister Hukum di University of Pennsylvania. Dari jenjang pendidikan tersebut, mengantarkan Khaled sebagai pengacara dan sekaligus mengajar di Universitas Texas. Ph.D 
nya didapat di University of Princeton dalam bidang Pemikiran Hukum Islam dengan gelar Doctor of Philosophy, dan pada saat bersamaan ia juga menempuh studi hukum di UCLA, University of California Los Angeles. (Nasrullah, 2003:163)

Pada tahun 1989, ia bekerja di Pengadilan Tinggi Arizona, Arizona Supreme Court menangani persoalan hukum keimigrasian dan komersial, Commercial and Immigration Law. Sejak saat itu ia diakui menjadi warga negara Amerika. Aktivitasnya di UCLA mengantarkannya pada puncak karir, menjadi profesor hukum Islam di University of California Los Angeles, School of Law.

Pengetahuan yang luas dan kontribusi yang ia sumbangkan ke dunia menjadikan dirinya mendapatkan banyak penghargaan dan apresiasi dari masyarakat antara lain: (a) University of Oslo Human Rights Award. (b) Pada tahun 2007 dia dianugerahi Lisler Eitenger Prize. (c) Tahun 2005 mendapatkan anugerah Carnegei Scholar in Islamic law. (d) Khaled pernah ditugaskan oleh Presiden George Washington Bush untuk menjadi pemantau dalam komisi untuk kebebasan beragama internasional (U.S. Commission for International Religious Freedom). (e) Khaled juga sebagai anggota Dewan Direktur pemantau hak azasi manusia (Human Rights Watch). (f) Sebagai anggota dewan penasihat middle east watch serta bekerja dengan organisasi Hak Asasi Manusia seperti: Amnesty Internasional And the Lawres Committe for Human Rights sebagai ahli dalam pemecahan berbagai kasus tentang HAM, terorisme, hukum komersial dan internasional. (g) Tahun 2005, Khaled juga termasuk sebagai salah satu dari 500 pengacara terbaik.

Khaled juga merupakan sosok penulis produktif, terbukti dari banyaknya karya antara lain: Islam and the Chelllengge of Democracy (Princeton University Press, 2004), The Place of Tolerance in Islam (Cambridge University, 2001), Rebellion dan Violence in Islamic Law (Cambridge University, 2001), Speaking in God Name: Islamic Law, Authority, dan Woman (One 
world Publication, 2001), And God knows the Soldiers: The Authoritative and Authoritarian in Islamic Discourse (2001), Conference of The Books: The Search for the Beauty in Islam (2001). Juga masih terdapat banyak artikel dan jurnal akademik yang ia tulis. Diantaranya telah dialih bahasakan kedalam Bahasa Arab maupun Indonesia.

\section{Pemikiran Khaled Tentang Konsep Otoritas}

Dalam diskursus keislaman kontemporer, Khaled menggunakan otoritas sebagai konsep dasar untuk mengkaji teori hermeneutiknya. Ia melakukan pembacaan bertolak dari pembedaan Friedman mengenai otoritas, yakni memangku otoritas, being in authority dan memegang otoritas, being an authority. Being in authority dimaksudkan sebagai kekuasaan untuk mengeluarkan instruksi atau arahan karena faktor posisi struktural dalam suatu institusi resmi. Dalam hal ini, seseorang bisa saja berbeda pendapat dengan pemangku otoritas, namun tidak mempunyai alternatif lain kecuali mematuhinya. Kepatuhan terhadap pemangku otoritas lebih merupakan kepatuhan terhadap jabatan atau kapasitas resmi seseorang. (Khaled, 2003:37)

Berbeda dengan pemangku otoritas, kepatuhan terhadap pemegang otoritas merupakan kepatuhan terhadap seseorang yang memiliki keahlian khusus. Kepatuhan dipahami sebagai pelimpahan wewenang kepada seorang yang ahli dalam bidang tertentu. Pada praktiknya, seseorang meninggalkan pendapat pribadinya karena patuh pada pemegang otoritas yang dipandang memiliki pengetahuan, kebijaksanaan, atau pemahaman yang lebih baik, meskipun si penerima otoritas tidak memahami dasar argumentasi dari pemegang otoritas. Kepatuhan semacam ini mengandung arti bahwa sesorang menyerahkan nalarnya kepada kehendak dan keputusan orang lain, yakni si pemegang otoritas. Dengan kata lain, ia telah melimpahkan dan memberikan kepercayaan kepada pemegang otoritas untuk menguji dan mengkaji nilai sesuatu yang harus ia yakini 
dan jalankan. (Khaled, 2003:38)

Khaled sependapat dengan apa yang dikatakan oleh Fridman. Namun ia memiliki istilah sendiri, otoritas koersif dan otoritas persuasif. Otoritas koersif dimaksudkan sebagai kemampuan untuk mengarahkan perilaku orang lain dengan cara membujuk, mengambil keuntungan, dan menghukum, sehingga tidak ada alternatif lain kecuali mematuhinya. Kepatuhan dalam otoritas koersif diperoleh melalui kekuasaan yang bersifat memaksa. Di lain pihak, otoritas persuasif melibatkan kekuasaan yang bersifat normatif, yakni kemampuan untuk mengarahkan keyakinan atau perilaku seseorang berdasarkan kepercayaan. Otoritas ini melibatkan penggunaan pengaruh dan kekuasaan normatif atas seseorang untuk percaya dan bertindak dengan cara meyakinkan mereka tentang suatu hal. (Khaled, 2001:40)

Perbedaan pokok otoritas koersif dan otoritas persuasif. Otoritas koersif tidak memerlukan upaya persuasi untuk dipatuhi. Sementara otoritas moral, sebaliknya, menekankan pentingnya persuasi bagi sebuah keputusan atau instruksi untuk dihormati, yang membuat orang lebih memilih arah keyakinan atau tindakan tertentu dan menolak kemungkinan yang lain. Abou Khaled menggarisbawahi bahwa relasi otoritas, baik yang persuasive maupun yang koersif, bersandar pada seperangkat representasi yang termanifestasikan dalam sejumlah klaim, seperti klaim tentang kekuasaan, wewenang, atau pengetahuan. (Khaled, 2003:105) Konsep ini akan menjadi menarik jika ditarik pada pemahaman teks, antara pengarang dan pembaca. Karena jika tidak hati-hati salah satu dari tiga elemen tersebut akan menjadi dominan.

Dalam Konsep Islam, Otoritas ini pastilah disandarkan kepada Allah sebagai pemegang otoritas paling absolut dan benar yang tersurat dalam kitabullah al-Quran. Sunnah sebagai otoritas kedua belum terjamin keautentikannya karena masih membutuhkan pembuktian kualitasnya. Pertanyaan selanjutnya yang muncul bagaimana menguji autentitasnya, 
dan kemudian bagaimana kedua otoritas tersebut dipraktikkan ke dalam keseharian. Hal ini mengandung makna bahwa proses interpretasi tidak hanya dalam upaya pencarian makna semata, tetapi bagaimana dapat dipraktekkan dalam kehidupan.

Selanjutnya Khaled menyebut sebagai otoritarianisme, yaitu siapakah yang paling berwenang dan memiliki kompetensi untuk menentukan makna. (Khaled, 2002:47) Apakah setiap individu atau sebuah institusi tertentu, yang dalam hal Ini Khaled banyak mengkritik beberapa institusi yang dirasa tidak terbuka dalam memberikan penjelasan, yang mengakibatkan Islam terkesan memaksa dan banyak teks keagamaan yang dianggap tidak adil.

Bagi kaum muslim, media paling meyakinkan untuk mengetahui kehendak Tuhan adalah al-Quran dan Sunnah. Sebagai teks yang mengklaim memuat kehendak Tuhan, maka perlu dilakukan uji kualifikasi atas al-Quran dan Sunnah. Dalam uji kualifikasi ini, menurut Khaled, seseorang harus membuat asumsi-asumsi berbasis iman bahwa al-Quran bersifat abadi dan terpelihara kemurniannya. Kompetensial-Quran dengan demikian, tidak bisa digugat. Sejauh menyangkut al-Quran, pertanyaan yang relevan bukanlah apakah al-Quran terpercaya, melainkan adalah bagaimana menentukan maknanya. (Khaled, 2003:127).

Kandungan al-Quran secara historis, merupakan respon langit terhadap realitas bumi. Ayat-ayat al-Quran akan membumi dalam kehidupan umat Islam jika teks tersebut dipahami dan ditafsirkan secara dinamis, praktis, dan kontinyu. Al-Quran selayaknya dijadikan sebagai teks terbuka dengan tidak mengesampingkan pesan moral yang terkandung di dalamnya. (Iyubenu, 2015:46)

Di sisi lain, sunnah memiliki tingkat kompetensi yang berbeda dari al-Quran. Perbedaan ini terkait dengan kompleksitas dan beragamnya sumber mengenai suatu riwayat tertentu. Untuk menguji dan menilai otentisitas riwayatriwayat semacam itu, para ahli hadith telah mengem- 
bangkan penelitian tentang mata rantai perawi. Dalam konteks hukum Islam, otentisitas sebuah riwayat harus dihubungkan dengan konsekuensi hukumnya. Khaled menyebutnya sebagai persyaratan proporsionalitas. Dalam hal ini otoritas Nabi harus diterima sebagai sebuah asumsi berbasis iman. Keputusan Nabi harus diikuti sejauh keputusan itu menginformasikan kehendak Tuhan. (Khaled, 2003:128) oleh sebab itu, tidak semua perkataan atau perbuatan Nabi membawa konsekuensi hukum.

\section{Pemikiran Khaled Tentang Hermeneutik Otoritarianisme}

Perhatian pemikir Muslim modern meningkat seiring interaksi kesadaran mereka dengan modernitas. (Rippin, 1993:86) Kesadaran tersebut berkaitan dengan kepentingan menciptakan model-model penafsiran yang terhadap al-Quran dengan bantuan kesadaran dan beragam metodologi ilmiah yang tersedia. Hal tersebut menimbulkan kecurigaan bahwa ilmuan Muslim menafsirkan al-Quran bukan demi menyingkap makna sejati, tetapi untuk mengejar tujuan ekstra qur'ani demi menghilangkan kesenjangan intelektual antara sesama ilmuan Muslim. (Rahman, 1991:93)

Persoalan tersebut merupakan dilema intelektual yang harus dipecahkan oleh para pemikir Muslim. Di satu sisi berkewajiban menafsirkan al-Quran sesuai tuntutan ilmiah objektif, sementara di sisi lain terdapat kepentingan moral untuk menjelaskan kebutuhan umat Islam menghadapi problem zaman. Dua sisi tersebut tidak saling menafikan, namun bagai dua mata uang yang saling melengkapi. (Saenong, 2002:93) Pemikir Muslim dalam hal ini dapat dibedakan menjadi dua kategori metodologis. Pertama, mereka yang menjelaskan teks secara objective kemudian baru ditarik dalam persoalan umat. Kedua, berangkat dari realitas kontemporer umat kemudian menuju pemahaman yang sesuai dengan ajaran Islam yang sebenarnya. (Senong, 2002:94) Dua kerangka di atas merepresentasikan pandangan hermeneutik al-Quran yang teoritik (metodologis) yang bercorak filosofis. 
Dalam Hermeneutik dikenal istilah triadic hermeneutic, yakni teks, author, dan reader. Khaled memposisikan ketiganya dalam posisi yang seimbang. Pertama, Teks dalam pengertianhat heremeutik secara umum. Al-Quran merupakan teks tertulis (written text) yang diyakini seperti halnya teks yang beredar selain al-Quran. (Hidayat, 1996:1) Sebuah teks tidaklah mampu berbicara sendiri tanpa ada adanya reader. Reader bebas menafsirkan sebuah teks dengan kajian bahasa yang ada, latar belakang penulis, sosial, kebutuhan, serta bebas karena penafsiran bersifat relative sesuai situasi dan kondisi yang ada.

Namun berbeda dengan Khaled, yang menganggap al-Quran tidaklah seperti teks biasa. Meskipun semua yang "mampu" menafsirkannya berhak untuk melakukan interpretasi, namun tidak dibenarkan reader otoritarianisme terhadap teks al-Quran. Al-Quran memiliki integritas tersendiri dibanding teks lain. Jika reader meninggalkan latar belakang lahirnya teks, dan membiarkan teks itu berbicara dalam bahasa dan symbol-nya saja, maka teks tersebut akan menjadi teks yang berdiri sendiri-tanpa pengarang. Hal ini menjadikan Khaled beralasan pentingnya meninggalkan otoritarisme teks, karena al-Quran sebagai fatwa keagamaan jika dibiarkan berbicara sendiri maka teks reader satusatunya pemegang otoritas.

Kedua, pengarang (author). Secara historis suatu teks tidaklah bisa untuk dipisahkan dengan pengarangnya. (Hidayat, 1996:1) Pengarang telah mewadahi dan mempercayakan makna yang dikehendakinya ke dalam simbol-simbol bahasa yang dipahami oleh pembaca. Teks yang telah ditulis pengarang telah memisahkan dirinya dengan teks itu sendiri. Subyektifitas pengarang tidak bisa dipaksakan melalui struktur bahasa. Khaled menjelaskan jika teks telah menjadi milik public maka siapapun tidak dibenarkan melakukan interfensi terhadap makna teks. Pemisahan porsi antara teks dan pengarang ini bisa mereduksi makna teks, ataupun juga sebaliknya. Bisa menjadikan suatu teks memiliki makna yang 
kompleks. Sehingga alur berfikir dan logika haruslah selaras dan sistematis agar pencarian makna bisa didapatkan secara baik.

Jika dihadapkan dengan teks al-Quran, maka akan menjadi berbeda menurut Khaled. Teks al-Quran bersifat terbuka dan sekaligus tertutup. Tertutup berarti teks kebenaran al-Quran sudahlah sebagai keniscayaan yang bersumber dari Tuhan. Teks al-Quran bersifat terbuka mengandung pengertian teks tersebut bebas untuk ditafsirkan. Terbuka nermakna dinamis bisa terus berkembang. Tidak berarti al-Quran terbuka bagi semua jenis interpretasi, namun al-Quran mampu menampung gerak interpretasi yang dinamis, Shahih li kulli zaman wa makan.

Ketiga, pembaca (reader). Kehadiran pembaca di tengah teks yang bisu menjadikan teks memiliki makna. Teks telah tersaji dan pengarangpun tidak mengawal teksnya, sehingga pembaca bebas untuk melakukan interpretasi. Namun dalam hal ini Khaled membantah jika hal ini diterapkan dalam teks agama (al-Quran, Sunnah, dan fatwa ulama). Khaled tidak membiarkan begitu saja pembaca melakukan interpretasi tanpa pengawalan dan secara bebas melakukan penafsiran sesuai kehendaknnya. Terlebih jika pembaca membawa nama Tuhan, atau bahkan sebagai Tuhan dalam menafsirkan teks. (Sanaky, 2005:12)

Khaled merasa khawatir terhadap sikap individu ataupun institusi yang menjadikan pembaca sebagai satu-satunya yang menguasai teks, yang dalam hal ini setiap kajian Khaled dilakukan dalam rangka menanggapi fatwa yang beredar dan dikeluarkan oleh lembaga resmi Arab Saudi, CRLO. Kegelisahan tersebut melahirkan metode hermeneutik otoritarianisme, yakni sebuah metode yang menolak kekuasaan absolut terhadap suatu teks selain Tuhan. Sebagaimana dipaparkan sebelumnya, kedaulatan mutlak adalah milik Tuhan. Di sisi lain, Islam mengakui peran kekhalifahan manusia. Namun, peran menentukan manusia ini membuka otoritarianisme jika ia bertindak di luar batas kewenangan hukum yang dimilikinya. Resiko yang dihadapi dalam hal ini adalah bahwa kehendak 
Tuhan akan tunduk pada pemahaman dan kehendak manusia.

Untuk itu Khaled memberikan parameter bagi syarat keberwenangan manusia sebagai wakil Tuhan (pakar hukum). Ada lima syarat yang harus dipenuhi seorang wakil Tuhan, diantaranya: (a) Kejujuran (honesty). Wakil Tuhan harus memiliki kejujuran dan dapat dipercaya untuk menerjemahkan perintah Tuhan. Ia harus menghindari keberpuraan memahami apa yang sebenarnya tidak diketahui, dan bersikap jujur tentang sejauh mana ilmu dan kemampuannya dalam memahami perintah Tuhan. (b) Ketekunan (dilligence) dalam mengerahkan segenap kemampuan rasionalitasnya untuk menemukan dan memahami kehendak Tuhan. (c) Komprehensifitas dalam menyelidiki kehendak Tuhan. Seorang penafsir harus melakukan penyelidikan perintah-perintah Tuhan secara menyeluruh dengan mempertimbangkan hal-hal yang relevan, dan tidak melepas tanggungjawabnya untuk menyelidiki atau menemukan alur pembuktian tertentu. (d) Penggunaan rasionalitas dalam penafsiran dan analisis terhadap perintah-perintah Tuhan. Penafsiran teks harus dilakukan secara rasional, atau setidaknya dengan ukuran yang benar menurut paradigma umum. Artinya, pembaca tidak boleh berlebihan dalam menafsirkan teks sehingga melahirkan kesimpulan bahwa makna teks tersebut benar-benar seperti yang diinginkan pembaca, dan bukan menampilkan maksud yang memang dikehendaki teks. (e) Pengendalian diri atau kerendahan hati dalam menjelaskan kehendak Tuhan. Pengendalian ini lebih merupakan kewaspadaan tertentu untuk menghindari penyimpangan, atau kemungkinan penyimpangan atas peran pengarang (Tuhan). (Khaled, 2003:99)

\section{Pemikiran Khaled Tentang Penerapan Konsep}

Khaled melakukan kajian terhadap beberapa fatwa CRLO yang kemudian menghasilkan sebuah metode hermeneutik otoritarianisme. Beberapa fatwa diantaranya: 


\section{"Tentang Ketaatan Kepada Suami"}

"Apa pendapat Anda tentang perempuan yang tidak mendengar perkataan suaminya, tidak mematuhinya, dan membantahnya dalam sejumlah persoalan. Misalnya, seorang istri yang pergii tanpa izin suami"

"Haram: Seorang perempuan harus mematuhi suaminya dalam kebaikan. Ia diharamkan membantah suaminya dan tidak diperbolehkan meninggalkan rumah tanpa seizin suaminya." Kemudian fatwa ini didukung hadits tentang laknat terhadap istri yang tidak memnuhi keinginan suami, hadits keutamaan suami yang bahkan seandainya boleh bersujud maka istri pantas bersujud". (Khaled, 2003:401)

Tanggapan Khaled terhadap fatwa di atas: Artinya: Diceritakan dari Ummi Salamah bahwa Nabi Muhammad SAW berkata: "Seorang istri yang meninggal dan suaminya ridha kepadanya maka ia akan masuk surga". (at-Turmuzi, tt: 388) Dari hadits tersebut tidak lantas menjadikan dan melahirkan fatwa bahwa istri harus taat suami dalam keadaan apapun dan akan dilaknat jika membangkang. Khaled menjelaskan bahwa hadits-hadits misoginis dalam memahami memerlukan jeda ketelitian hadits tersebut bertentangan dengan gambaran sifat Nabi dan berlawanan dengan semangat al-Quran, dengan melihat hadits dan al-Quran yang bertentangan, karena spirit al-Quran mengenai cinta, kasih sayang, persahabatan, kesalehan, dan ketaatan kepada Tuhan. Para ahli hukum klasik dan modern menyatakan bahwa jika ada pertentangan antara berbagai sumber kita harus mendalami sumber-sumber tersebut. Jika kita merujuk pada teks hadits, hadits-hadits yang digunakan CRLO adalah hadits-hadits ahad, sehingga tidak bisa menandingi ke autentisitasannya dengan al-Quran yang mutawattir.

Terlepas dari perdebatan kebolehan hadist ahad manasakh alQuran ini, Khaled juga menjelaskan secara hukum positif bahwa hadits tersebut memiliki dampak sosial, teologis, dan politik yang serius jika fatwa tersebut ditelan begitu saja. (Khaled, 2003:318) Jadi dalam mengeluarkan suatu fatwa hendaklah mempertimbangkang aspek sosial sebagai dampak dari fatwa tersebut. 
Persoalan wanita yang semakin intens bermunculan semakin membutuhkan kesadaran bahwa pentingnya memahami dan menghidupkan kembali wawasan Islam mengenai wanita. Hal ini terjadi akibat benturan budaya yang terjadi antara dialektika dan realita. Persoalan tersebut absah terjadi secara outentik dan sejati (benar-benar muncul dari keinginan murni). Di samping itu, munculnya permasalahan wanita juga disebabkan karena reaksi yang bersifat apologetik, ideologis, dan terkadang subyektif. (Madjid, 1995:279)

Dari contoh kasus tersebut, dapatlah diluruskan kembali dengan merujuk kepada sumber suci, al-Quran dan Sunnah Nabi. Semangat dasar kearifan asasi atau hikmah ajaran kitab suci dan hadits nabi secara terbuka memberikan pemahaman ajaran Islam yang menyeluruh tanpa diskriminasi, sehingga kebutuhan dalam melakukan penafsiran diharapkan akan memberikan implikasi terhadap kebutuhan umat dalam menghadapi segala permasalahan yang ada.

\section{Simpulan}

Persoalan otoritarianisme agama menjadi kegelisahan utama Khaled M. Abou Khaled sebagaimana terbaca pada beberapa karyanya. Otoritarianisme agama terjadi ketika fikih diperlakukan sebagai kehendak mutlak Tuhan, padahal fikih lebih merupakan refleksi sejarah dalam memahami pesan ketuhanan, bersifat situasional dan bergantung kepada konteks sosial yang melahirkannya. Pada konteks ini, Khaled menawarkan hermeneutika otoritatif sebagai kritik sekaligus perangkat metodologis untuk membedah dan menafsirkan teks-teks keislaman, khususnya dalam khazanah hukum Islam.

Adanyahermeneutikotoritarianisme, diharapkan pemikiranKhaled mampu meng-counter fatwa-fatwa yang otoritarianisme, memaksakan diri seolah menjadi paling benar. Sehingga dapat mendamaikan umat dan memperbaiki citra Islam di mata dunia. Khaled yang merupakan 
Profesor Hukum Islam berusaha menguasai secara menyeluruh konsep hukum yang dikupasnya. Latar belakang pendidikannya menjadikan lebih komperhensif dalam melakukan interpretasi teks sesuai dengan kebutuhan umat, dengan mempelajari hermeneutik otoritarianisme Khaled, diharapkan seseorang akan semakin bijak dalam menyikapi sesuatu, dan tidak gegabah dalam melakukan tindakan yang begitu mudahnya mengatasnamakan Tuhan dan menghakimi kelompok lain, terlebih dalam menyikapi masalah fiqh terutama isu-isu kontemporer.

\section{Daftar Pustaka}

At-Turmuzi, Muhammad Bin Isa Abu Isa. tt. Sunan at-Turmuzi. Juz IV. Beirut: Dar Ihya' At-Turats al-'Arabi.

Khaled, Khaled M. Abou. 2003. Speaking in God's Name: Islamic Law, Authority, and Woman. (terj) Cecep Lukman Yasin. Atas Nama Tuhan: Dari Fiqh Otoriter ke Fiqh Otoritatif. Jakarta: Serambi Ilmu Semesta.

2003. The Authoritative and Authoritarian in Islamic Discourse: A case Study. (terj) Kurniawan Abdullah. Melawan Tentara Tuhan: Yang Berwenang dan Sewenang-wenang dalam Wacana Islam. Jakarta: Serambi Ilmu Semesta.

. 2001. Rebellion and Violence in Islamic Law. Cambridge: Cambridge University Press.

. 2002. The Place of Tolerance in Islam. Boston: Beacon Press.

Hidayat, Kamaruddin. 1996. Memahami Bahasa Agama: Sebuah Kajian Hermeneutik. Jakarta: Paramadina.

Iyubenu, Edi AH. 2015. Berhala-Berhala Wacana: Gagasan Kontekstualisasi Sakralitas Agama Secara Produktif-Kreatif. Yogyakarta: Ircisod.

Palmer, Richard. 2005. Hermeneutics Interpretation Theory in Schleirmacher, Dilthey, Heidegger, and Gadamer diterjemahkan oleh Masnuri Hery dan Damanhuri dengan judul Hermeneutika; Teori Baru Mengenai 
Interpretasi. Yogyakarta: Pustaka Pelajar.

Madjid, Nurcholis. 1995. Islam Agama Peradaban: Membangun Makna Relevansi Doktrin Islam dalam Sejarah. Jakarta: Paramadina.

Matswah, Akrimi. 2013. "Hermeneutika Negoisatif Khaled M. Abou Khaled Terhadap Hadis Nabi". Jurnal ADDIN. vol. 7, no. 2.

Nasrullah. 2008. "Hermeneutika Otoritatif Khaled M. Abou Khaled: Metodologi Kritik Atas Penafsiran Otoritarianisme Dalam Pemikiran Islam". Jurnal Hunafa. vol. 5, no. 2.

Sanaky, Hujair. 2005. "Gagasan Khaled Abou Khaled Tentag Problem Otoritarianisme Tafsir Agama Pendekatan Hermeneutik dalam Studi Fatwa-fatwa Keagamaan". Jurnal al-Mawardi. edisi XIV.

Saenong, Ilham B. 2002. Hermeneutika Pembebasan: Metodologi Tafsir alQur'an. Yogyakarta: Teraju.

Rahman, A.N.M. Wahidur. 1991. Modernist Approach to the Qur'an, Islam and the Modern Age. New Delhi. p. 91-94.

Rippin, A. Muslim. 1993. Their Religious Beliefs and Practices Contemporary Period. New York: Routlegde.

Sumaryono, E. 1993. Hermeneutik. Yogyakarta: Kanisius.

Talchah, Muhammad Hasan. 2003. Diskursus Islam Kontemporer. Jakarta: Lista Fariska Putra.

Zarkasyi, Hamid Fahmy. 2006. Hermeneutika Sebagai Produk Pandangan Hidup. Kairo: KPM Cabang 